\title{
Mythology, poetry and theology
}

\author{
Alphonso Groenewald \\ Department of Old Testament Studies \\ University of Pretoria
}

\begin{abstract}
Der Mensch lebt nicht mehr in einem bloß physikalischen, sondern in einem symbolischen Universum. Sprache, Mythos, Kunst und Religion sind Bestandteile dieses Universums.
\end{abstract}

(Cassirer 1969:50)

\begin{abstract}
Human beings have always been mythmakers. However, in view of the heavy negative connotations attached to the word "myth", the aim of this article may, inter alia, be seen as an attempt to "rehabilitate" the word "myth" as a positive term in order to describe one of the most common genres within the Old Testament tradition. The author will indicate that the presence of myth is a common phenomenon in the Bible, and specifically in the Psalter (as poetry). The authors of the Psalms used (re-used) myth, the "mythical" and/or mythical allusions in order to express some of their most profound theologising about Yahweh - the God of Israel as well as their relationship to that God.
\end{abstract}

\section{INTRODUCTION}

Human beings have always been mythmakers. From a very early date, therefore, it appears that homo sapiens were distinguished by their ability to have ideas that went beyond their everyday experience (Armstrong 2005:2). They are thus meaning seeking creatures. They have an imagination, a faculty that enables them to think of something that is not immediately present, and that, when they first conceive it, has no objective existence. This imagination is the faculty that produces religion and mythology. However, for quite some time mythical thinking was in disrepute. It was often dismissed as irrational and self-indulgent. The word "myth" was used to describe something that is simply not true.

The theme of this article is about myth and mythmaking in the Old Testament, and specifically in the Psalter. Just a few decades ago such a topic would have been unimaginable - given the circumstances as sketched 


\section{Mythology, poetry and theology}

in the first paragraph. Jews and Christians alike have always interpreted myth, supposedly, as an antithesis of what is regarded as revealed religion (Batto 1992:1). Myth was rather seen as belonging to pagan religion - it was false belief. By definition, then, myth could not exist within the Bible - or the Word of God. ${ }^{1}$

However, in the last three and a half decades, since the 1970s, ideas have begun to change. Myth has been increasingly recognised as an important theological medium, and therefore is seen as part and parcel of the biblical tradition; specifically the Old Testament tradition. It seems that scholars have gained a new appreciation for the ancient genres in which biblical authors wrote. Myth is one of those genres, although its centrality in biblical tradition has neither been sufficiently recognised, nor worked out thoroughly.

This article is, however, not offered in the hope that suddenly a bright light will shine on every mythological crux in the Old Testament, but rather with the aim of presenting an overview of myth, as well as some of the definitions offered for this literary genre. In the last section of this article I suggest one possible way in which we can understand this genre as we encounter it in the Psalter.

\section{DEFINING MYTH: AN OUTLINE}

Parts of the Old Testament have been classified by many scholars as "myth" or "mythology". The so-called Primeval History (Gn 1-11) seems to be heavily dependent upon the mythic tradition of Mesopotamia (Batto 1992:2). Other portions of the OT are more dependent on Canaanite myth(s). For example, the Combat myth - whether in its Babylonian or Canaanite form - underlies to some extent virtually every aspect of Israel's historically based faith. The Exodus narrative is less of an historical account than a mythic interpretation of this event, and namely as a second act of creation. In this narrative the Egyptian host does not as such represent an earthly enemy, but rather the incarnation of the chaos dragon. The prophets also resorted to the Combat Myth to express their belief that in the background of historical threats to Israel we find an evil power which should be overcome (Batto 1992:3). However, when we read the literature dealing with this topic, it becomes evident that there has been, and still is, a great deal of debate among

\footnotetext{
${ }^{1}$ Cf also Smend (1991:16): "Ein Vorgang wie die Anwendung des Mythosbegriffs auf die biblische Geschichte mußte herkömmlicher Theologie ein Stein des Anstoßes sein. Aber für die Bibelwissenschaft war er nur folgerichtig, nachdem sie einmal auf dem Wege war, die biblischen Bücher als Dokumente einer vergangenen Zeit geschichtlich zu verstehen und dabei die übernatürlichen Faktoren immer mehr zurücktreten zu lassen."
} 
scholars concerning a single definition of "myth", ${ }^{2}$ as well as the role it played in ancient society and literature (Oden 1992:946). In this regard Schmidt (1995:3) justly infers as follows: "Die Schwierigkeit, das Verhältnis des Alten Testaments zum Mythos zu bestimmen, besteht darin, daß das Verständnis von Mythos selbst nicht eindeutig ist". In spite of the attention devoted to "myth" over the past two hundred years, nearly every student of this phenomenon can only lament the difficulty of formulating a truly adequate definition of myth. ${ }^{3}$ Closer still to desperation is the statement made by Rogerson (1974:173) that "finding an adequate and all-purpose definition of myth" remains an "impossible task". It therefore comes as no surprise that all past attempts to identify or list myths in the Bible, according to a specific theoretical definition, represent a problematic task as a result of the divergent use of the term within biblical studies (Smith 1994:293).

This seems to be the situation in spite of the fact that the term "myth" has been part of biblical sciences, even since the era of the Aufklärung. We also cannot fool ourselves regarding the problematic usage of the term "myth" as well as its problematic application to biblical texts (Irsigler 2004b:9). This, partly, seems to be the result of the origins of the word mythos, as well as its application in the history of the Greek literature (Schmidt 1995:3f). ${ }^{4}$ Originally the Greek term mythos referred to a tale, or something which was spoken loudly. Within this semantic range we can encompass phenomena which are as diverse as a public speech, a conversation, a narrative, and even the plot of a story or a play (Batto 1992:4). It gradually happened that this term became more restricted in its semantic meaning(s). From the time of the poet Pindar ( $5^{\text {th }}$ century BCE), mythos acquired the notion of fiction. The Sophists introduced the distinction between the two terms mythos and logos. To them the latter was identical with what can be depicted as factual; the former (mythos) was seen as something which was unhistorical. In a similar manner the philosopher Plato used the term mythos in the sense of early Greek legends in which human, as well as divine action and activities are often intertwined. This suggests that at its best, one is dealing here with poetic metaphor rather than with historical reality. Accordingly, with time the term mythos came to mean primarily an imaginative or fictional story. We can even go a step further: the word came to mean a false story or a fabrication - a

\footnotetext{
${ }^{2}$ Cf Irsigler (2004b:9): "Die Sprach- und Begriffsverwirrung in Sachen 'Myhos' ist groß."

${ }^{3}$ Cf Irsigler (2004a:7): “'Mythos' ist ein ebenso viel gebrauchtes wie vieldeutiges Wort.”

${ }^{4} \mathrm{Cf}$ in this regard also Irsigler (2004b:10): "Es war der griechische Mythos vorab als traditionelle Geschichte oder Erzählung von Göttern und Heroen, der weithin bestimmt hat, was als Mythos zu verstehen sei."
} 


\section{Mythology, poetry and theology}

meaning which our word "myth" still has in some contexts. Etymology, which normally is the traditional point of departure, thus does not seem particularly helpful in this case (Kirk 1970:8).

Oden (1992:946-960) provides us with a useful critical survey of some recent theories of myth. ${ }^{5} \mathrm{~A}$ complete list of all these definitions and theories would however be neither useful nor possible in the present context of this paper. I will restrict myself to a few. One of the first definitions given was used by modern folklorists. When they began to study myth, they only used the definition which was generally made known to us by the Grimm brothers, namely that myths are stories about the gods (cf also Schmidt 1995:3-4). This definition, however, has its limitations - it proved to be inadequate as it implies at the same time too much and too little. It implies too much in its suggestion that myths are and can only be limited to a polytheistic setting. First of all, the question can be raised: what about a monotheistic setting? Secondly, it excludes any traditional tales told which do not contain the "gods" as characters. As the classicist Kirk (1970:9) observes, while some myths deal with the gods, others are not about the gods at all, and they do not have any ancillary implications with regard to sanctity or taboos. We can refer, for instance, to Gilgamesh who was certainly treated for the most part as a king and not as a god and who, in spite of a divine mother, was to become the archetype of royal mortality. On the other hand, the definition does not imply enough: it was not sufficiently specific. To state that myth is simply a story about the "gods" does not do justice to the complexity of the issue at hand.

At present it seems that in order to qualify as a myth, scholars are beginning to agree, the specific material should contain the following four characteristics: ${ }^{6}$ (i) it should be a story or narrative; (ii) the material should be traditional, that is, almost always transmitted orally within a communal setting and for a long time; (iii) these traditional stories must deal with a character or characters who are more than merely human; and (iv) the final criterion, myths should relate events from remote antiquity. Given these four criteria, Fontenrose's definition seems quite adequate: it is characterised by its brevity, as well as its inclusion of three of the criteria listed above (Fontenrose 1971:54). According to him myths could be defined as "the traditional tales of

\footnotetext{
${ }^{5}$ Cf also Gaster (1962:481-487); Hübner (1994:597ff); Müller (2002:1689ff); Schmidt (1994:625ff); Segal (2002:1682ff); Smith (1994:294ff).

${ }^{6}$ Rogerson (1974:174-178) identifies twelve possible meanings or characteristics in order to qualify as a myth (cf also Schmidt 1995:3ff).
} 
the deeds of daimones: gods, spirits, and all sorts of supernatural or superhuman beings" (cf also Petersen 1982:31). ${ }^{7}$

Irsigler (2004b:13-14) provides us with a somewhat more elaborate theory of myth. He summarises the characteristics of this genre in the following seven points:

1) A "myth" can fundamentally (i.e. on a primary level) be described as a narrative mode of expression which was orally transmitted. On a secondary level, it is a literary text type which is significant for the collective self-understanding of a specific culture. A myth can occur in the form of a traditional significant narrative, a history or a narrative sequence which describes an incident, the order of events or an important happening. Whatever may be, they are converted into different images.

2) Numinous beings, that is to say a deity or a number of deities, participate in the narrated event. They can act within the scope of their relationship to one another or even in relationship to human beings.

3) The event which is narrated, namely in the form of the myth, normally takes place in circumstances which are open for change - that is to say, there is a movement from a position of instability towards a (positive or negative) position of stability.

4) These events are being told as non-recurring incidents, even when they refer to repetitive events occurring either in nature or in the human world.

\footnotetext{
${ }^{7}$ According to Swiggers (1999:188f) the essential properties of a minimal definition of myth should include the following five points:

(a) Myth is a narrative, which usually involves a certain degree of literary elaboration;

(b) A myth is meant as a true story about the holy - i.e. about a transcendental experience of man;

(c) The mythical story is situated in non-historical times: it is "meta-historical" or "extra-temporal", since it is precisely the myth that installs the conditions for human reality;

(d) Myth is furthermore an anonymous narrative and belongs, as a collective property, to the community. Each member of the community is introduced to the mythical universe through the stories that are told within the community;

(e) The mythical content is paradigmatic: it sets an example for the conduct of man, or intends to show how man has to behave before god/the gods. The paradigmatic nature of the myth - its message being repeated over and over again - is intimately tied up with its "extra-temporal" character.
} 
5) The time of the event, as being told in the myth, has an extra-temporal character. It stands in direct contrast to human time which can be understood either as historical time or as contemporary time. The myth thus happens in pre-historical times, primitive times, or proto-typical times during which current conditions of existence are established. The story being told or described thus has a pre-historical character.

6) The sphere of the event is in principal not restricted to one single space. It, on the other hand, has numinous qualities, e.g. the mountain of the gods, the garden of God, the temple, etc. This space is often outside the direct accessible, namely heaven or the underworld. It, nevertheless, can have a direct influence on human lives.

In a functional sense the myth proclaims basic human experiences put against the background of a secret and threatening world. The events in the myth are examples of human existence and activity. The myth describes the establishment of natural order. It thus accounts for the present reality - it substantiates, it legitimises, it explains, it interprets.

Oden (1992:949ff; cf also Batto 1994:7ff) furthermore also lists some meanings and functions of myths. Reference can be made to the following:

- Myth, like science, is an attempt to explain. ${ }^{8}$ Mythology and science both extend the scope of human beings. Like science and technology, mythology is not about opting out of this world, but about enabling us to live more intensely within it. This theory finds in both myth and science an expression of the human desire to explain puzzling phenomena. The only significant difference is that myth comes from an early stage in human development, whilst science comes from a later (or more advanced) stage.

\footnotetext{
${ }^{8}$ Reference can be made to the theories offered by e $g$ Edward B Taylor and James G Frazer. Cf for example the following statement made by Lambert (1988:124-125): “... it may be defined as primitive man's attempt to come to grips with the natural forces around him. By primitive man, man living in primitive circumstances is meant, that is, not so fully mastering the environment and its potentialities that he was free from risks from a failed harvest, for example. He really needed the co-operation of nature to survive ... The 'primitiveness' of his thought results from his limited understanding of the forces of nature, as compared with ourselves, on account of lack of modern science and related dogma. Thus myth embraces primitive man's science, religion and philosophy. It is thus his attempt to understand the world of nature."
} 
- Myths are expressions of the "mythopoeic" mind..$^{9}$ Myths, accordingly, are products of a different kind of thinking, a different kind of thought altogether. Mythopoeic thought works expressively, mystically, and poetically - such thought seeks to participate with phenomena, and does not explain them.

- The myth-ritual theory. ${ }^{10}$ According to this theory, one should always regard myths to be interrelated to the rituals which accompany them. The reason is namely that myths and rituals are two parts of a single phenomenon. Myths - one can say - are the spoken counterpart of that, which is performed during the ritual. Many myths make no sense outside a liturgical drama that brings them to life, and are incomprehensible in a profane setting.

- Myth and society. ${ }^{11}$ According to this theory one should look first and foremost to the social setting of myths. Myths are traditional stories, that is to say, they have their origins as well as their transmission within a communal setting and context. This theory argues that the function of myth is therefore precisely to cement social bonds - that is to say, to bring together disparate people as a group and subsequently to support their group identity. According to adherents of this theory it can also be formulated as follows: a myth is not an intellectual explanation as such, nor is it an artistic imagery, but rather a pragmatic charter of primitive faith and moral wisdom (cf also Strenski 1987:42ff).

- Myth and the unconscious. ${ }^{12}$ This theory is the psychological equivalent to the social theory which has just been referred to. According to its adherents, myths function to fulfil individual, psychological needs. This view therefore presupposes the existence of

\footnotetext{
${ }^{9}$ Reference can be made to the theories developed by e $\mathrm{g}$ the French anthropologist Lucien Lévy-Bruhl and Ernst Cassirer.

${ }^{10}$ Reference can be made to the theory developed by e $\mathrm{g}$ William $\mathrm{R}$ Smith. The major biblical scholars influenced by this theory include e g Sigmund Mowinckel and Theodor H Gaster.

${ }^{11}$ Reference can be made to the theories developed by e $\mathrm{g}$ William R Smith, Emile Durkheim and Bronislaw Malinowski.

${ }^{12}$ Reference can be made to the theories developed by Sigmund Freud and Carl G Jung. According to Armstrong (2005:11) "the stories of gods or heroes descending into the underworld, threading through labyrinths and fighting with monsters, brought to light the mysterious workings of the psyche, showing people how to cope with their own interior crises. When Jung and Freud began to chart the modern quest for the soul, they instinctively turned to classical mythology to explain their insights, and gave the old myths a new interpretation."
} 
an unconscious: the human unconscious needs expression - and the origin and meaning of any myth is to be sought in this need.

- The theory called structural analysis, which is especially linked to the French anthropologist Claude Lévi-Strauss. He compares myth to language, and sees in linguistics a key to understanding myth. Phonemes as such have no meaning - meaning is only produced by their interrelationship with one another. The same can be said of the elements in myths: mythic elements only produce meaning by the structure of their relationship with one another, hence the reason for calling this theory "structuralism".

- The phenomenological approach to the history of religions seeks to provide an objective study of the actual religious experiences of humankind. ${ }^{13}$ According to phenomenologists myths are regarded as sacred stories which are set in time outside of "profane" or secular time (Batto 1992:10). ${ }^{14}$ The function of myth is to reveal the exemplary models for all human rites and significant human activities. Despite the multiplicity of forms that religious phenomena have in various cultures, they are all manifestations of the same basic religious impulse in humankind.

- What has become evident from the preceding discussion is the fact that the notion of "myth" is an extremely complex one (Swiggers 1999:187). In general terms, we can define myth as a story about the holy, about gods, and even as a foundational story about the origins of humankind and of the universe. People all want to know where they come from, but because their earliest beginnings are lost in the mists of prehistory, they created myths about their forefathers that are not historical, but help to explain current attitudes about their environment, neighbours and customs. People also want to know where they are going therefore they devised stories that speak of a posthumous existence.

\footnotetext{
${ }^{13}$ Reference can be made to the theories developed by Gerardus van der Leeuw and Mircea Eliade. The narrow definition of myth, as interpreted by Eliade, can be formulated as follows: "Für Eliade ist der Mythos eine (meist heilige) paradigmatische Ursprungsgeschichte, die durch eine ontophanische Struktur gekennzeichnet ist, wodurch sie dem Menschen eine Ontologie (insbesondere eine Kosmologie und eine Anthropologie) vermittelt, mit deren Hilfe er sich in der Welt orientieren kann und an die er seine existentiell wichtigen Handlungen rückbindet" (Mohn 1998:134).

${ }^{14}$ Cf also Schmidt (1995:4): "Der Mythos 'hebt die Zeit auf'; er geschieht 'typisch und ewig', 'außerhalb aller Zeitlichkeit'.”
} 
We can, however, conclude this section by stating that it seems impossible and even undesirable to try to find a single exclusive definition for the term "myth" (cf also Armstrong 2005:1-11; Rogerson 1974:174).

\section{MYTH AND THE OLD TESTAMENT}

Myth is a universal human phenomenon, which attempts to express ultimate reality through symbols (Batto 1992:11). This implies that myth points towards a reality which is beyond itself and thus cannot be directly symbolised. It transcends both the capacity of discursive reasoning and expression in ordinary human language. Every society - ancient and modern - has its myths and is involved in mythmaking. Both myth (in general) and the OT (in particular) have as their ultimate concern an understanding of reality (Childs 1960:7). ${ }^{15}$ The authors of both myth and the OT also tried to cope with the problematic human predicament, and to find their place in the world. Myth is one of the important mediums used by the biblical writers to theologise. Like their ancient Near Eastern counterparts, Israel's theologians were concerned with their place within humankind and within the realm of being (Batto 1992:169).

It has become evident from the preceding discussion that the word "myth" indicates a complex term which reflects a specific world view, a specific view of life, a mythical form of thinking or mentality structure (Irsigler 2004b:10). In spite of this acknowledgement, we must accept the fact that in the biblical arena "myths" are only accessible to us through the medium of the texts and the textual structures. Whatever the mythical form of thinking is or may be, the only entrance accessible to us, is by means of its textual markers (whether in prose or in poetry), its imagery as well as its graphic constellations.

Throughout the history of the composition of the Hebrew Bible its writers used and re-used myth to undergird their religious and socio-political agenda. ${ }^{16}$ Instead of trying to read myth out of the OT - as has been done in the past - one should acknowledge the fact that myths permeate virtually every layer of biblical tradition from the earliest to the latest (Batto 1992:1). The broad definition of myth suggests that a great deal of the material in the

\footnotetext{
${ }^{15}$ Cf in this regard also Von Rad (2005:213): “... the religion of Israel was intensely interested in the world, which it saw in direct and immediate relationship to God."

${ }^{16}$ According to Irsigler (2004b:18) "Israel schöpft wie seine altorientalische Um- und Mitwelt aus einem reichen tradierten kulturellen Wissenfundus an mythischer Bildsprache und mythischem Erzählungsgut, die als 'anthropomorph-adäquate, speicherbare und abrufbare Programme' wirken".
} 


\section{Mythology, poetry and theology}

Hebrew Bible - not just selected borrowings - qualifies as mythic (Oden 1992:949). The exegete should thus acknowledge the fact that texts from all periods and of virtually every literary genre reveal to us the fact that the biblical writers borrowed old myths and extended their meanings in creative ways in order to express new theological insights. ${ }^{17}$ The genre of the text(s) will determine the specific intention or usage of the mythical element(s) in the text. Mythical language occurs in narratives, but also in other literary contexts, for example in hymns, prayers or in prophetic words (Irsigler 2004b:18).

A hundred years ago most of these mythical allusions in the OT texts would have passed unnoticed (Gaster 1969:xxv). However, as a result of archaeological discoveries from Mesopotamian, Canaanite, Hittite and Egyptian literature, it is possible to recognise that the OT is in fact saturated with the popular traditions of the Ancient Near East. For example, the notion that water preceded all things likewise occurs in Babylonian and Egyptian mythology. Both also attest the creation of man from clay. Another example can be referred to, namely Leviathan - the monster vanquished primordially by $\mathrm{YHWH}$ and destined to be vanquished again at the end of the present era (Isa 27:1) - is now known to be the Hebraization of Leviathan vanquished by Baal in an earlier Canaanite myth from the city of Ras Shamra-Ugarit.

Myth, in the narrow sense as stories about gods, hardly occurs in the literature of the OT (Irsigler 2004b:18). The only texts we can refer to in this sense are maybe, first of all, the short story about the marriage of the sons of the gods with the daughters of mankind in Genesis 6:1-4. ${ }^{18}$ Secondly, in Ezekiel 28:11-19 we find a lamentation about the king of Tyre: the basis of this lamentation is the myth about the casting out of primeval man from the mountain of the gods (and also from the garden of God). ${ }^{19}$

Mythical narrative, in a theological re-moulding, occurs in its most profound form in Genesis 1-11. Reference can be made, for example, to the first creation narrative that we encounter in Genesis 1. It can be read as a poised, calm polemic against the old belligerent Babylonian cosmogonies

\footnotetext{
${ }^{17}$ Cf also Irsigler (2004b:12) in this regard: "Nun ist weitgehend unbestritten, dass sich in den Literaturen Griechenlands und Mesopotamiens, Ugarits und Kleinasiens, in begrenztem Maß auch in Ägypten "mythische“ Erzählungen mit gleichartigen Merkmalen, z.T. in unterschiedlichen Literaturformen finden und dass "mythische Motive“ im Alten Testament vorrangig kanaanäischen, aber auch mesopotamischen und ägyptischen Hintergrund verraten bzw. eher die Teilhabe Israels an einem traditionellen Reservoir oder Arsenal mythischer Bildsprache und Vorstellungen."

${ }^{18}$ According to Van Wolde (1997:121) "Genesis 6, 1-4 is een vreemd stukje tekst. Het is een mythologische miniatuur waarin godenzonen met mensendochters paren ... De achtergrond waartegen dit verhaal gelezen moet worden is die van een pluriform godsbeeld."

${ }^{19}$ According to Zimmerli (1969:688) "das hier erzählte Fürsten schiksal ist erzählt im Bilde des
} 
(Armstrong 2005:95). In calm, ordered prose this new creation myth looks at the Babylonian cosmology from a doubtful angle. Yahweh - unlike Marduk does not need to fight desperate battles to create the world. He brings all things effortlessly into existence through a single command. The sun, moon, stars, sky and the earth are not gods in their own right; they are not hostile to Yahweh, but are rather subservient to him. Tiamat is Yahweh's creature who obeys him - he is not a sea-monster anymore. Yahweh's creative acts are so superior to Marduk's - they do not need to be repeated or renewed again. Whereas the Babylonian gods were engaged in an ongoing battle against the powers of chaos, Yahweh can simply rest on the seventh day - his work is complete.

It seems that the Israelites were quite happy to use the old Ancient Near Eastern mythology when it suited them. A mythological presentation of the story of the Exodus occurs both in the forms of prose and poetry. The exodus is described as a primeval, extra-temporal archetypical character of events. Mythical motives occur especially in poetical texts, for example the kingship of Yahweh within the context of a heavenly royal court, or the mountain of God and the garden of God. Reference can be made to the phenomena "death" and the "realm of death", which act as so-called personal powers. As a rule, all of these have been taken out of their original foundational and associative context, in order to be re-used in a new functional manner. ${ }^{20}$

Smith (1994:299) postulates that if there was ever a text which scholars call a myth, it is the Ugaritic Baal Cycle (cf also Cross 1973:112ff). Biblical narrative or poetry which thus centre on the action of at least one divine figure, and which is comparable to the narrative we encounter in the Baal Cycle, can then be called a "myth". ${ }^{21}$ However, if biblical material uses divine

\footnotetext{
${ }^{20}$ Cf also Irsigler (2004b:19-20): "Der Altmeister der alttestamentlichen Gattungsforschung Hermann Gunkel schreibt in begeisterten Tönen von der Fülle und Kraft des Mythischen, das bei den hebräischen Dichtern überliefert und verarbeitet ist. Ich zitiere einen Passus aus seiner "Israelitischen Literatur" (1963 [1925], 17), der an seine berühmte vereinfachte Definition des Mythos als einer Erzählung, deren handelnde Personen Götter sind, d.h. einer "Göttergeschichte" anschließt: "Eine erstaunliche Fülle mythischen Stoffes aber ist uns bei den hebräischen Dichtern aus allen Zeiten überliefert; ... Und was für ein dankbarer Stoff sind diese altorientalischen Mythen mit ihren brennenden Farben und ihrer gewaltigen

Leidenschaft! ... So ist denn die poetische Sprache im Hebräischen des Mythischen übervoll: da wird das Totenreich unter der Erde einem grimmigen Ungetüm verglichen, das den Rachen aufsperrt ohn' Maßen (Jes. 5,14), oder einer gewaltigen Festung mit unzerbrechlichen Toren und Riegeln (Jes. 38,10; Jonas 2,7); oder das hebräische Klagelied beschreibt die Hadesfahrt des Toten, der zu den Wassern der Unterwelt hinabmuß, wie man in heidnischen Mythen etwa von Ištars Höllenfahrt sprechen mag".

${ }^{21}$ Cf also Herrmann (1987:104): “..., daß hinsichtlich der in mythischer Urzeit erfolgten Bekämpfung des Meeres und dessen göttlicher Repräsentanten Jahwe im Glauben seiner Verehrer wie schon in anderer Weise an die Stelle Baals trat. Oder anders gesagt: die Vorstellung, die sich mit Baal als Widerpart Yammus verband, wurde in Israel schließlich gleichfalls auf Jahwe übertragen."
} 


\section{Mythology, poetry and theology}

magery or motives comparable to the divine imagery or motives from the Baal Cycle, they may be characterised as "mythic imagery" or "mythic motives". The divine imagery attested in the Baal Cycle so fully suffuses Israelite narrative, prayer and other genres that it would seem that mythic narratives and imagery were quite popular in ancient Israel. In the new appropriation the original values are translated as symbols. The OT tradition offers us a continual adaptation of myth over the course of a few hundred years in order to meet the changing needs of a dynamic faith community. ${ }^{22}$ This process is not only a dynamic process, but also represents a conscious and reflected application of older myths and mythic elements to new situations.

\section{THE "MYTHICAL" IN THE PSALMS}

In the poetry of the OT and of the Psalms, there is evidence of a standard mythological vocabulary, drawn from the Umwelt (Gaster 1969:xxviii). Some examples will be referred to, though not extensively. The primeval Dragon is smitten (Ps 68:21) or roared at (Ps 104:7), as in the texts of Ras ShamraUgarit; the abode of God is in the far north (Ps 48:2), as in the Ugaritic myths. The members of the heavenly court are "sons of God" (Pss 29:1; 89:6), as in Canaanite and Akkadian literature. YHWH chariots upon the clouds (Ps $104: 3)$, as Baal does. Reference is also made to the "dragons in the water" and Leviathan (Ps 74:13-14), leading us back to Ugaritic texts. Gaster (1969:xxxiv) sees the role of myth in the Psalms as follows: myth envisages and expresses things in terms of their impact. Its concern is with experience; it articulates a present, existential situation. No wonder that it finds expression in poetry. Myth, as an existential experience, is thus the natural language of religion.

At this point it seems appropriate to establish a minimal starting-point from which the analysis of texts from the Psalter can proceed. In the subsequent discussion the term "myth" will not be used in the sense of a literary or proto-literary genre, but - in accordance with Hans-Peter Müller (1991:4) - rather with the meaning "mythical". This refers to the quintessence of both the content and function of this genre, as well as its understanding of the self and of reality. ${ }^{23}$ According to Zenger (1999:233) it can be asserted that in poetry, as a matter of fact, we encounter such a specific understanding

\footnotetext{
${ }^{22}$ Cf also Herrmann (1987:104): "Dennoch ist der Forschung heute deutlich, daß die Bevölkerung der syrisch-palästinischen Landbrücke nicht nur manches Rezipierte eigenständig verarbeitete, sondern ebenso eigene Werte hervorbracht."

${ }^{23}$ Cf Müller (1991:4): "Wir sprechen in folgenden meist nicht vom Mythos als einer literarischen bzw. protoliterarischen Gattung, sondern vom 'Mythischen' und meinen damit den Inbegriff der in der Gattung Mythos zur Geltung kommenden Inhalte und Funktionen bzw. des ihnen entsprechenden Selbst- und Wirklichkeitsverständnisses".
} 
of "mythical". ${ }^{24}$ This is true in as far as poetry, by means of the medium of language, constitutes a world which simultaneously presents a counterworld. $^{25}$

Poetical texts generate a new world of meaning which is based on distinctive subject-matters, traditions and motives. Irsigler (2004b:20) postulates that in psalmic poetry we encounter, what he calls, a substratum effect of "myth". By means of this concept he indicates the following: typical terms and motives are indicators of mythical connections; even when this substratum is being superimposed, or a new meaning given to it, or else it is functionalised by means of new language levels and specific textual intentions. This taking-over of mythical motives from their original or even older contexts into a new context implies the existence of a relationship between both areas, namely the old as well as the new context.

Poetry utilises mythical imagery and mythical constellations in order to present the experienced world as a profound dimension. ${ }^{26}$ The readers and hearers of such poetry engage in this profundity the moment when their reality and the poem's reality coalesce (Zenger 1999:233). This poetical constitution of the religious counter-world undoubtedly utilises "mythical" language especially when its aim is to master the brokenness as well as radical changes taking place in both collective as well as individual lives.

Scholarship has time and again emphasised the fact that, specifically, Israel's experience of the collective catastrophe in the $6^{\text {th }}$ century led to a major revitalization of mythical traditions. ${ }^{27}$ This process was even

\footnotetext{
${ }^{24}$ In this regard Gunkel (1963 [1925]:17) has already noted the following: "So ist denn die poetische Sprache im Hebräischen des Mythischen übervoll". Cf also Irsigler (2004b:20): "Wir können jedoch das Mythische zunächst bewusst heuristisch im weiten Sinn interpretieren als alle möglichen Arten von Bezugnahmen in Prophetie und Psalmen auf vorausgesetzte Mythen, deren Inhalte, Strukturen und Funktionen, seien es Anspielungen, Konnotationen, mythische Textelemente oder mythische Motive, die losgelöst von ihren ursprünglichen Mythen-Kontexten in andersartigen sprachlichen Kontexten begegnen".
}

${ }^{25}$ Cf Zenger (2003:viii): "In ihrer poetischen Metaphorik und ihrer pragmatischen Textdynamik konstituieren sie ein bestimmtes »Weltbild « ... Konstituiert der Psalm poetisch eine »Welt», so ist dies eine sprachliche Aneignung der Wirklichkeit, um in dieser und mit dieser leben zu können".

${ }^{26}$ Cf also Gaster 1962:481: "Myth is that expression of the creative imagination which interprets the real in terms of the ideal".

${ }^{27}$ Cf e g Herrmann (1987:126-129): "Auch unten den Judäern hat es zur babylonischen Zeit keine Wiedergeburt alter Lebens- und Denkstrukturen gegeben. Vielmehr wurde Überkommenes verlebendigt und deutlich zur Wirkung gebracht ... Dahinein gehört nun die erneute Aktivierung mythologischen Guts unter den Judäern ... Im Mythos fanden die Judäer Stoff vor, der sich als Gewandung für neue und weitergreifende Ideen anbot und den sie dazu heranziehen konnten, Jahwe als denjenigen zu rühmen, der in der Lage war, übermächtig die ihm entgegenstehenden Gewaltigen zu überwinden und zu zerschlagen ... Jahwe eigneten alle bis dahin bekannten Grenzen übersteigende Prävalenz und Erhabenheit ... Diegenigen, die sich ausschließlich an inn gebunden wußten, bezeugten inn als einen, der über die Götterwelt dominierte, dessen Majestät den Erdkreis umspannte und dessen Aktivität seiner Schöpfung galt". 


\section{Mythology, poetry and theology}

furthermore enhanced by the prolonged effect of uncertainty which the postexilic epoch had on the individual. The impact of shattered social foundations also enhanced this process. Indeed, the world in which the texts of the OT were created, was a down-to-earth kingdom. Here people had to struggle for their future against the all-too-human fears of war, poverty, injustice, disease, famine and drought (Finkelstein \& Silberman 2002:1).

In the Psalms of Israel we encounter the "mythical" in a variety of ways. Through the medium of language the Psalms lead their readers into an alternative encounter with the transcendental reality, which differs from the traditional encounter the cult offered them. These "mythical" texts therefore do not need the cultic ritual and space anymore as "time" and "space" in order to enter into the world of the divine. These texts rather represent the "space" and "time" of the divine presence. ${ }^{28}$ This statement leads us to an important hermeneutical principle which should be emphasised. The exegete should always be aware of the fact that these texts integrate the customary (i.e. the everyday) into the "mythical" (Zenger 1999:234). In order to interpret the Psalms as religious poetry, he/she should always pay exact attention to this integrated perspective. It seems that all religious realities are based upon the assimilation of the metamorphoses of different realities. We thus cannot have conscious representations of God which do not contain mythical aspects. ${ }^{29}$

\section{CONCLUDING REMARKS}

In view of the strong negative connotations attached to the word "myth", the aim of this article may, inter alia, be seen as an attempt to "rehabilitate" the word "myth" as a positive term in order to describe one of the common and important activities in biblical tradition. It has been demonstrated that the presence of myth is a common phenomenon within the Bible; and within the Psalter as well. It seems that the authors of the Psalms made use of myth in order to do some of their most profound theologising about Yahweh - the God of Israel - as well as their relationship to that God.

\footnotetext{
${ }^{28}$ Cf also Zenger (2003:viii): “Die Poesie übernimmt die Kraft des Rituals und konstituiert Lebenssinn."

${ }^{29}$ Cf in this regard Irsigler (2004b:22): "Einerseits wirkt das Gottesverständnis, das sich in den Texten ausprägt, als der entscheidende Maßstab der Rezeption und Transformation des Mythischen, andererseits ist dieses in größerem oder geringerem Maß eine notwendige und elementare Dimension der Rede von Gott, die eine lebendige, menschennahe Gottesvorstellung hervorruft und prägt."
} 


\section{Works consulted}

Armstrong, $\mathrm{K}$ 2005. A short history of myth. Edinburgh: Canongate.

Batto, B F 1992. Mythmaking in the Biblical tradition: Slaying the dragon. Louisville, KY: Westminster/John Knox.

Cassirer, E 1969. Philosophie der symbolischen Formen, II: Das mythische Denken. Darmstadt: Primus Verlag.

Childs, B S 1960. Myth and reality in the Old Testament. London: SCM. (Studies in Biblical Theology.)

Cross, F M 1973. Canaanite myth and Hebrew epic: Essays in the history of the religion of Israel. Cambridge: Harvard University Press.

Finkelstein, I \& Silberman, N A [2001] 2002. The Bible unearthed: Archaeology's new vision of ancient Israel and the origin of its sacred texts. New York: Touchstone.

Fontenrose, J 1971 [1966]. The ritual theory of myth. Berkeley, CA: University of California Press. (University of California Folklore Studies 18.)

Gaster, T H 1962. Art. "Myth, Mythology". IDB 3, 481-487.

Gaster, T H 1969. Myth, legend and custom in the Old Testament: $A$ comparative study with chapters from Sir James G Frazer's Folklore in the Old Testament, Vol 1. London: Harper \& Row.

Gunkel, H [1925] 1963. Die israelitische Literatur. Darmstadt: WBG. [Nachdruck der Ausg. Leipzig 1925].

Herrmann, W 1987. Das Aufleben des Mythos unter den Judäern während des babylonischen Zeitalters. Biblische Notizen 40, 97-129.

Hübner, K 1994. Art. "Mythos". TRE 23, 597-608.

Irsigler, H 2004a. Vorwort, in Irsigler, H (Hrsg) 2004, Mythisches in biblischer Bildsprache. Gestalt und Verwandlung in Prophetie und Psalmen, 7-8. Freiburg: Herder. (QD 209.)

Irsigler, H 2004b. Vom Mythos zur Bildsprache: Eine Einführung am Beispiel der "Solarisierung" JHWHs, in Irsigler, H (Hrsg) 2004, Mythisches in biblischer Bildsprache: Gestalt und Verwandlung in Prophetie und Psalmen, 9-42. Freiburg: Herder. (QD 209.)

Kirk, G S 1970. Myth: Its meaning and functions in ancient and other cultures. Cambridge: Cambridge University Press.

Lambert, W G 1988. Old Testament mythology in its ancient Near Eastern context, in Emerton, J A (ed), Congress volume: Jerusalem 1986, 124143. Leiden: Brill. (S VT 40.)

Mohn, J 1998. Mythostheorien: Eine religionswissenschaftliche Untersuchung zu Mythos und Interkulturalität. München: Wilhelm Fink Verlag.

Müller, H-P 1991. Mythische Elemente in der jahwistischen Schöpfungserzählung, in Müller, H-P, Mythos - Kerygma - Wahrheit: Gesammelte Aufsätze zum Alten Testament in seiner Umwelt und zur biblischen Theologie, 3-42. Berlin: Walter de Gruyter. (BZAW 200.)

Müller, H-P 2002. Art: Mythos/Mythologie. RGG 5, 1689-1692.

Oden, R A 1992. Art: Mythology, Myth in the OT. ABD 4, 946-960. 
Petersen, C 1982. Mythos im Alten Testament: Bestimmung des

Mythosbegriffs und Untersuchung der mythischen Elemente in den

Psalmen. Berlin: Walter de Gruyter. (BZAW 157.)

Rogerson, J W 1974. Myth in Old Testament interpretation. Berlin: Walter de Gruyter. (BZAW 134.)

Schmidt, W H 1994. Art. Mythos. TRE 23, 625-644.

Schmidt, W H 1995. Mythos im Alten Testament, in Graupner, A et al (eds), Vielfalt und Einheit alttestamentlichen Glaubens, Band 1: Studien zu Hermeutik und Methodik, Pentateuch und Prophetie, 3-20. NeukirchenVluyn: Neukirchener Verlag.

Segal, R A 2002. Art. Mythos/Mythologie. RGG 5, 1682-1687.

Smend, R 1991. Epochen der Bibelkritik: Gesammelte Sudien Band 3. München: Chr. Kaiser Verlag. (BET 109.)

Smith, M S 1994. Mythology and myth-making in Ugaritic and Israelite literatures, in Brooke, G J et al (eds), Ugarit and the Bible: Proceedings of the International Symposium on Ugarit and the Bible Manchester, September 1992, 293-341. Münster: Ugarit-Verlag. (UBL 11.)

Strenski, I 1987. Four theories of myth in twentieth-century history: Cassirer, Eliade, Lévi-Strauss and Malinowski. lowa City, IA: University of lowa Press.

Swiggers, P 1999. Babel and the confusion of tongues, in Lange, A et al (Hrsg), Mythos im Alten Testament und seiner Umwelt: Festschrift für Hans-Peter Müller zum 65. Geburtstag, 182-195. Berlin: Walter de Gruyter. (BZAW 278.)

Van Wolde, E [1995] 1997. Verhalen over het begin: Genesis 1-11 en andere scheppingsverhalen. Baarn: Ten Have.

Von Rad, G [1958] 2005. From Genesis to Chronicles: Explorations in Old Testament Theology, edited by K C Hanson and translated by E W T Dicken from the original German, Gesammelte Studien zum Alten Testament. München: Chr. Kaiser Verlag. (Theologische Bücherei 8.) Minneapolis, MN: Fortress Press. (Fortress Classics in Biblical Studies.)

Zenger, E 1999. Das Mythische in den Psalmen 84 und 85, in Lange, A et al $(\mathrm{Hg})$, Mythos im Alten Testament und seiner Umwelt: Festschrift für Hans-Peter Müller zum 65. Geburtstag, 233-251. Berlin: Walter de Gruyter. (BZAW 278.)

Zenger, E 2003. Vorwort, in E Zenger (Hrsg), Ritual und Poesie: Formen und Orte religiöser Dichtung im Alten Orient, im Judentum und im Christentum, vii-ix. Freiburg: Herder. (HBS 36.)

Zimmerli, W 1969. Ezechiel 2: Ezechiel 25-48. Neukirchen Vluyn: Neukirchener Verlag. (BKAT XIII/2.) 